\title{
Influence of fluvial discharge on the dynamics of Chlorophyll- $\alpha$ in the continental shelf adjacent to the Recife Port Basin (Pernambuco-Brazil)
}

\author{
Amanda Yumi Otsuka ${ }^{*}$, Fernando Antônio do Nascimento Feitosa ${ }^{1}$, Manuel de Jesus Flores \\ Montes $^{l}$, Alex Costa da Silva ${ }^{l}$
}

${ }^{1}$ Departamento de Oceanografia da Universidade Federal de Pernambuco

(Av. Arquitetura S/N, Recife - PE - 50740550 - Brazil)

*Corresponding author: amanda.otsuka@gmail.com

\begin{abstract}
This study was undertaken in the coastal zone of the state of Pernambuco adjacent to the Recife port area, which corresponds to the inner shelf. This research aimed to analyze the dynamics of chlorophyll- $a$ and several other environmental variables. Sampling was undertaken bimonthly on the surface from September 11th to May 10th, thus including the rainy and dry periods, and during low tide in spring tide. The parameters analyzed were chlorophyll$a$, salinity, temperature, transparency, dissolved oxygen, oxygen saturation rate, $\mathrm{pH}$, suspended solids, dissolved inorganic nutrients. Phytoplankton biomass ranged from 13.48 to $145.09 \mathrm{mg} \mathrm{m}^{-3}$ in the estuarine area and on the inner shelf, the variation being from 0.24 to $19.29 \mathrm{mg} \mathrm{m}^{-3}$ in the dry season and from 0.78 to $5.20 \mathrm{mg} \mathrm{m}^{-3}$ in the rainy season. PCA showed a direct relationship of chlorophyll- $a$ with ammonia, phosphate and transparency and an inverse relationship with suspended particulate matter and nitrate. Biomass did not vary significantly different as a result of seasonal or spatial dynamics. The estuary of the Capibaribe River is considered highly impacted, and as it forms the Recife port basin, it joins with two more strongly eutrophic water bodies, the Beberibe River and the Pina Basin, leading to an amplification of its influence on the adjacent shelf. In terms of the river plume's dispersion in the Port of Recife, the presence of a dike causes some disturbance in the direction of the current, limiting the plume to the area close to the coast and influences the oceanographic variables on the inner continental shelf.
\end{abstract}

Descriptors: Phytoplankton biomass, Spatial and temporal variability, Eutrophication, Environmental variables, Water quality.

\section{Resumo}

O presente trabalho foi desenvolvido na zona costeira do estado de Pernambuco adjacente a área portuária do Recife, correspondente à plataforma. Apresentou como objetivo analisar a dinâmica da clorofila- $a$ e variáveis ambientais. As coletas foram realizadas bimestralmente, na superfície, de maio/10 a setembro/11 englobando os períodos chuvoso e estiagem, durante a baixa-mar e em maré de sizígia. Os parâmetros analisados foram clorofila- $a$, salinidade, temperatura, transparência, oxigênio dissolvido, taxa de saturação do oxigênio, $\mathrm{pH}$, material em suspensão e nutrientes inorgânicos dissolvidos. A biomassa fitoplanctônica variou entre 13,48 e 145,09 $\mathrm{mg} \mathrm{m}^{-3}$ na área estuarina e na plataforma a variação foi de 0,24 a 19,29 $\mathrm{mg} \mathrm{m}^{-3}$ no período de estiagem e 0,78 a $5,20 \mathrm{mg} \mathrm{m}^{-3}$ no período chuvoso. A ACP evidenciou uma relação direta da clorofila- $a$ com N-amoniacal, fosfato e transparência e inversa com o material particulado em suspensão e nitrato. A biomassa não apresentou diferença significativa para sazonal e espacialidade. O estuário do rio Capibaribe é considerado altamente impactado, e ao formar a bacia portuária do Recife, este se soma a mais dois corpos d'água fortemente eutrofizados, o rio Beberibe e a Bacia do Pina, fazendo com que a influência na plataforma adjacente seja ampliada. Em termos de dispersão de pluma dos rios no porto do Recife, a presença do dique provoca uma certa perturbação no sentido da corrente, limitando esta pluma para a parte mais costeira e influencia as variáveis oceanográficas na plataforma interna.

Descritores: Biomassa fitoplanctônica, Sazonalidade e espacialidade, Eutrofização, Variáveis ambientais, Qualidade da água. 


\section{INTRODUCTION}

The coastal marine environment can be basically understood as a transitional area between the continents and the liquid marine mass that covers approximately $70 \%$ of the earth's surface. This continental/sea interaction zone is considered extremely complex from the biological point of view because it has within its limits a profusion of influences, terrestrial and atmospheric as well as oceanic, allowing its characterization as one of the most fertile and dynamic of the hydrosphere (Resurreição et al., 1996).

The dispersion of continental drainage waters in coastal areas has been recognized as an important physical process for coastal and river basin management. River and estuary waters generally flow out into the sea in such a way as to form a plume which transports sediments, nutrients and organic materials from the continent into the oceans (Stacey et al., 1999).

According to Abessa et al. (2012), the disposal of domestic effluents in the ocean, whether in shallow or deeper waters, can result in a series of negative environmental impacts, of which eutrophication and the flowering of toxic algae stand out. The planktonic community has a highly dynamic character, with considerable reproductive and loss rates, rapidly responding to the physical and chemical alterations of the aquatic environment and establishing complex intra and interspecific relations in the competition for and use of space and resources (Valiela, 1995). For this reason, some species of this community are used as bioindicators, offering an overview of the organisms' integrated response to environmental modifications.

Determining the productive capacity of an ecosystem consists of evaluating its real ability to maintain all the levels of the trophic web, and it is thus possible, by means of the phytoplankton biomass, to classify the environment as to its degree of eutrophication (Passavante and Feitosa, 2004).

There are still few works of phytoplanktonic biomass in the continental shelf area in Pernambuco and northeast region, among the past works of phytoplankton biomass, such as: Passavante et al. (1987/89), Passavante and Feitosa (1995); Passavante (1994/95), Moura and Passavante (1994/95), Resurreição et al. (1996), Medeiros et al. (1999) with data obtained in JOPS II, Azevedo et al. (2008) in Golfão Maranhense region and Mafalda et al. (2009) in REVIZEE.
The main aim of this study was to analyze the dynamics of chlorophyll- $a$ and of the hydrological parameters of the inner continental shelf area of Pernambuco under the influence principally of the plume of the Capibaribe River but also of other tributaries.

\section{MATERIAL AND METHODS}

The drainage basin of the Capibaribe River comprises an area of $7,552 \mathrm{~km}^{2}$, which is equivalent to $6.73 \%$ of the area of the state of Pernambuco. From source to mouth, the river runs through the Agreste and Zona da Mata regions, cutting through the metropolitan region of Recife and having a total length of approximately 250 kilometers (SRHE, 2010). At the end of its course, the Capibaribe River meets the Beberibe River and the Pina basin and flows out into the Atlantic Ocean at the latitude of the port of Recife. The climate of the Pernambuco coast is of the As' type, according to Köppen's classification, with an annual average temperature of $25.6^{\circ} \mathrm{C}$, average annual precipitation of 2,272.9 $\mathrm{mm}$ and prevailing southeasterly winds (Araújo et al., 1999; Porto do Recife, 2013).

The Capibaribe basin has an estimated population of 430,000 inhabitants and, among the main sources of the environmental degradation of this river, its pollution by urban and industrial waste stands out (SRHE, 2010). The estuarine system of the port of Recife presents a series of problems associated with the degradation of the environment of the continental shelf. The main problem is associated with the city's sewage system, which consists of isolated secondary subsystems (Noriega et al., 2013).

\section{FIELD STEPS}

Samples were collected at 5 sites, one inside the estuary, serving as the estuary site (P1), and four others on the inner continental shelf in a line parallel to the coast, site 2 (P2) being located $1.5 \mathrm{~km}$ south of the port of Recife, site 3 (P3) opposite the entrance to the port, followed by site 4 (P4) and site 5 (P5), this latter lying about $3 \mathrm{~km}$ north of the port. The distance between the collection sites and between them and the coastline is approximately $1.5 \mathrm{~km}$, except for P1 (Figure 1) (Table 1). Bimonthly collections were carried out in the period between May/2010 and September/2011, on board a lobster-fishing type boat, at during low tide in spring tide. Water samples for analysis of phytoplankton biomass (chlorophyll-a) and hydrological parameters were collected at the surface using Niskin oceanographic bottles. 


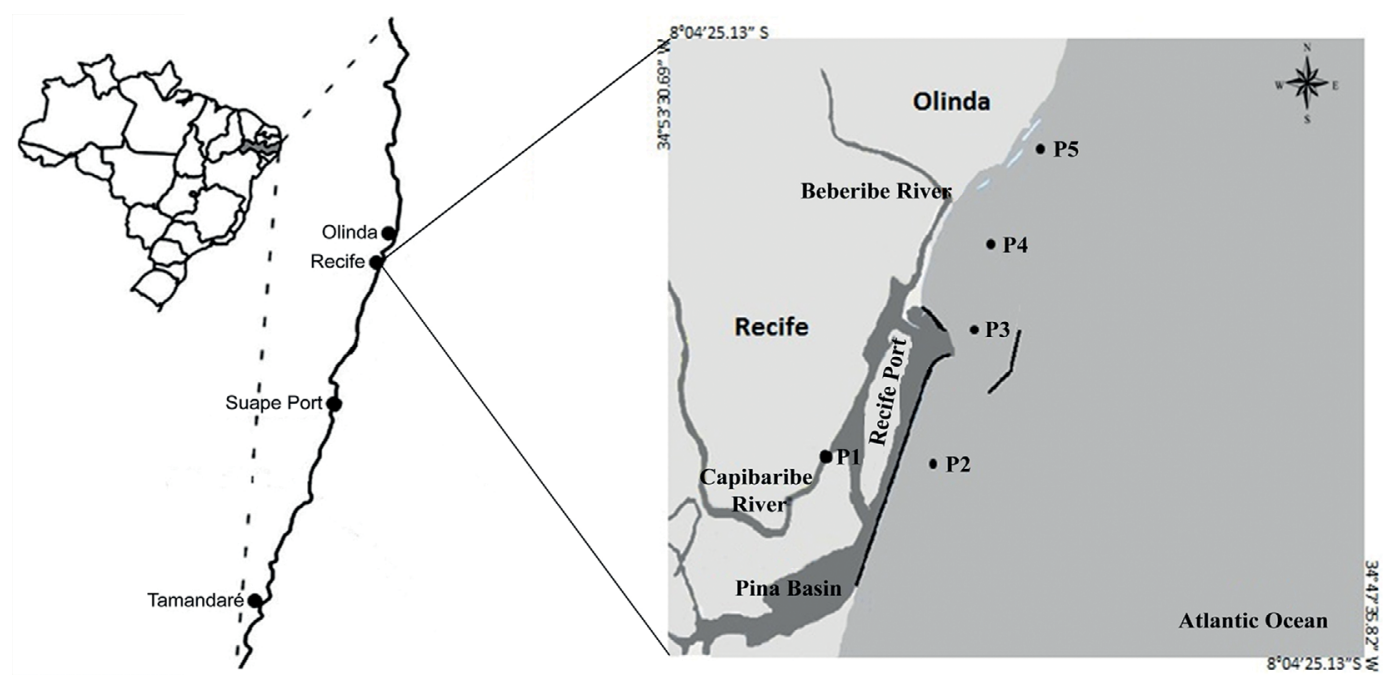

Figure 1. Location of the collection sites in the estuarine zone of the Capibaribe River (P1) and on the inner continental shelf (P2, P3, P4, P5) verage e to the port of Recife, PE Brazil. (Source: Google Earth, 2013).

Table 1. Sampling stations coordinates.

\begin{tabular}{lcc}
\hline Site & Latitude (S) & Longitude $(\mathrm{W})$ \\
\hline P2 & $8^{\circ} 3^{\prime} 47,09^{\prime}$ & $34^{\circ} 51^{\prime} 37,46^{\prime \prime}$ \\
P3 & $8^{\circ} 2^{\prime} 46,06^{\prime}$, & $34^{\circ} 51^{\prime} 17,73^{\prime}$, \\
P4 & $8^{\circ} 2^{\prime} 20,95^{\prime}$ & $34^{\circ} 50^{\prime} 57,27^{\prime}$ \\
P5 & $8^{\circ} 1^{\prime} 9,56^{\prime \prime}$ & $34^{\circ} 50^{\prime} 23,65^{\prime}$ \\
\hline
\end{tabular}

\section{LABORATORY MEASURES}

Water samples for the determination of chlorophyll- $a$ were filtered through Whatman $47 \mathrm{~mm}$ GF/C filters. The volume varied from 0.25 to $1.0 \mathrm{~L}$. Then the chlorophyll- $a$ was extracted in $90 \%$ acetone for 24 hours at $-18^{\circ} \mathrm{C}$. After this, the samples were centrifuged at 3,000 rpm for 10 minutes. The spectrophotometric method recommended by UNESCO (1966) was used, and the results expressed in $\mathrm{mg} \mathrm{m}^{-3}$.

Water transparency was measured in situ by means of a Secchi disk; the local depth was determined by using a digital echo sounder; dissolved oxygen was analyzed using the modified Winkler method described in Strickland and Parsons (1972); the dissolved oxygen saturation rate was calculated using the International Oceanographic Tables (UNESCO, 1973), correlating temperature and salinity values; $\mathrm{pH}$ was determined with a $\mathrm{pH}$ meter; nutrients ( $\mathrm{N}$-ammoniacal, nitrite, nitrate, phosphate and silicate) were analyzed using the method of Strickland and Parsons' (1972) and Grasshoff et al. (1983). Suspended particulate matter was determined using the gravimetric method described by Baumgarten et al. (1996).

Temperature and salinity data were obtained by Sea Bird Electronics SBE19 plus CTD equipped with centrifugal pump and high resolution sensors for conductivity measurements (resolution $=0.00004 \mathrm{~S} \mathrm{~m}^{-1}$ ), temperature (resolution $=0.0003^{\circ} \mathrm{C}$ ) and pressure (resolution $=0.068 \mathrm{db}$ ). Hydrodynamic parameters were measured using an Acoustic Doppler Current Profile (ADCP), or Doppler acoustic currentometer model RDI 600 to measure their movement in relation to the bottom as well as the distribution of suspended sediments in the measurement section.

For statistical analysis, the homogeneity of variances was tested using the Levene test. Data normality was ascertained with the Shapiro-Wilk test, and with normalized data, the factorial ANOVA test was performed on the Statistic 7 software to verify spatial and seasonal variations, considering $p$ values of $\leq 0.05$ significant. For the multivariate analysis of parameters, Principal Component Analysis (PCA) was used based on Pearson's moment-toproduct correlation matrix. Then the eigenvector and eigenvalue of the two main components were extracted. The calculations were performed using Statistic 7 software.

\section{RESULTS}

The average monthly rainfall in the study period was 260.2 $\mathrm{mm}$, with a maximum of $755.7 \mathrm{~mm}$ measured in May/2011 and a minimum of $23.5 \mathrm{~mm}$ in November/2010. Two periods were highlighted: the dry and the rainy. The dry season comprised the months of November/2010, February/2011, March/2011 and September/2011, which presented an average of $113.3 \mathrm{~mm}$, and in the rainy season, the months were May/2010, July/2010, May/2011 and July/2011 with an 
average rainfall of $429.5 \mathrm{~mm}$. Total rainfall was $1,933.4 \mathrm{~mm}$ in 2010 and 3,245.7 $\mathrm{mm}$ in 2011, when maxima were recorded in May/2011 (755.7 mm) and April/2011 (647.4 mm) and minima in November/2010 (23.5 mm) and September/2011 (35.7 $\mathrm{mm})$. Compared to the average value of the previous 20 years (1992-2011), which was 2,232.7mm, the year 2011 was seen to have had $45.37 \%$ more rain (Figure 2).

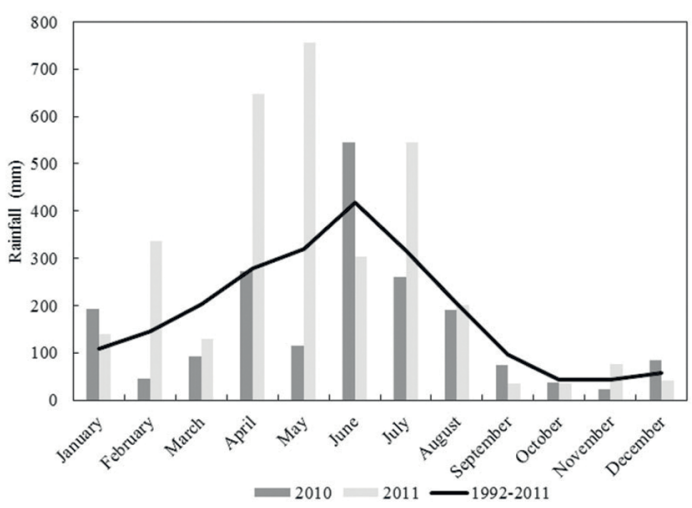

Figure 2. Rainfall data of 2010, 2011 and the verage verage of the previous 20 years (1992-2011). Source: INMET.

The mean depth of each sampling site was: $1.42 \mathrm{~m}$ at $\mathrm{P} 1$ (estuary), $9.74 \mathrm{~m}$ at $\mathrm{P} 2,10.71 \mathrm{~m}$ at $\mathrm{P} 3,8.79 \mathrm{~m}$ at $\mathrm{P} 4$ and $7.44 \mathrm{~m}$ at $\mathrm{P} 5$ (Table 2).

The water surface temperature showed a maximum value of $30.5^{\circ} \mathrm{C}$ at $\mathrm{P} 1$ (September/2011) and a minimum of $26^{\circ} \mathrm{C}$ at $\mathrm{P} 4$ (September/2011). Statistically, this parameter showed seasonal variation, the highest values being observed in the dry season (Table 2).

Salinity in the estuary (P1) was always low due to the greater fluvial influence, with a maximum of 16.31 (February/2011) and a minimum of 0.17 (July/2011). Of the inner continental shelf sites, P2 presented the low salinity value of 14.97 (May/2010), 24.76 (July/2011) and 25.57 (May/2011). In all the other months, salinity was higher than 33. At P3, salinity remained below 30 in almost every month except for September/2011 (35.83), March/2011 (35.36). At P4, salinity below 30 was found in July/2011 (12.91), May/2011 (24.23) and July/2010 (26.64). At P5, the lowest salinity values were found in July/2011 (22.88) and May/2011 (29.07) (Figure 3) (Table 2).

In order to identify the vertical structures of the physical parameters (temperature and salinity), measurements were taken along the water column at the 4 collection sites on the inner continental shelf during the sampling campaigns conducted in November/2010 and May/2011.
In November/2010, the surface temperature values were around $28.6^{\circ} \mathrm{C}$ at the four collection sites (P 2, 3, 4 and 5). During this period, the lowest water temperature values (around $28.2^{\circ} \mathrm{C}$ ) were observed near the bottom, at depths of $9 \mathrm{~m}$ (P 2) and $11 \mathrm{~m}$ (P 3). The analyses of vertical temperature structures showed a variation of about $0.4^{\circ} \mathrm{C}$ between the surface and the bottom along the water column (Figure 4).

During this period, low salinity $(<34)$ estuarine water was found at sites 3 and 4 , located at $0.5 \mathrm{~m}<1.0 \mathrm{~m}$ depth. At sites 2 and 5, there was no low salinity water mass at the surface of the water column, but there was a high salinity ( $>37$ ) peak at a depth of about 1 meter (Figure 4).

During the sampling campaign of May/2011, no large temperature variation was observed along the water column at the collection sites, with a maximum temperature variation of $0.5^{\circ} \mathrm{C}$ between surface and bottom. Maximum temperature values (around $28.3^{\circ} \mathrm{C}$ ) were recorded at $2 \mathrm{~m}$ depth at sites 4 and 5. At the same time, the presence of a low salinity water plume was observed at the four collection sites, with salinity values ranging from 16 to 34 (Figure 5).

The hydrogen potential $(\mathrm{pH})$ remained alkaline at all the sites sampled during both periods, ranging from 7.22 at P1 (September/2011) to 8.52 at P1 (May/2010). Statistically, this parameter showed no significant seasonal or spatial variation (Table 2).

Dissolved oxygen varied spatially. The lowest concentrations, ranging from $0.11 \mathrm{ml} \mathrm{L}^{-1}$ to $4.35 \mathrm{ml} \mathrm{L}^{-1}$, were found in the estuary (P1), the water being therefore considered almost anoxic. The inner continental shelf values ranged from $1.73 \mathrm{ml} \mathrm{L}^{-1}$ at P3 (July/2010) to $5.01 \mathrm{ml} \mathrm{L}^{-1}$ at P5 (November/2010), characterizing an unpolluted area (Table 2).

Statistically, the saturation percentage varied both seasonally and spatially. The estuary (P1) presented a minimum value of $2.42 \%$ in March /2011 and a maximum value of $78.3 \%$ in May/2011. At the other, coastal, sites, these values ranged from $35.58 \%$ at P3 (July/2010) to $114.1 \%$ at P5 (November/2010) (Figure 6) (Table 2).

The suspended particulate matter did not present any spatial or seasonal variation. In the estuary, it ranged from $18.6 \mathrm{mg} \mathrm{L}^{-1}$ (March/2011) to $210.91 \mathrm{mg} \mathrm{L}^{-1}$ (May/2011). At the sites on the inner continental shelf, the minimum was $3.6 \mathrm{mg} \mathrm{L}^{-1}$ at P5 (March/2011) and $55.6 \mathrm{mg} \mathrm{L}^{-1}$ at P4 (July/2011) (Figure 6) (Table 2).

The lowest values of water transparency were found in the estuary (P1), ranging from $0.1 \mathrm{~m}$ (July/2011) to 0.7 


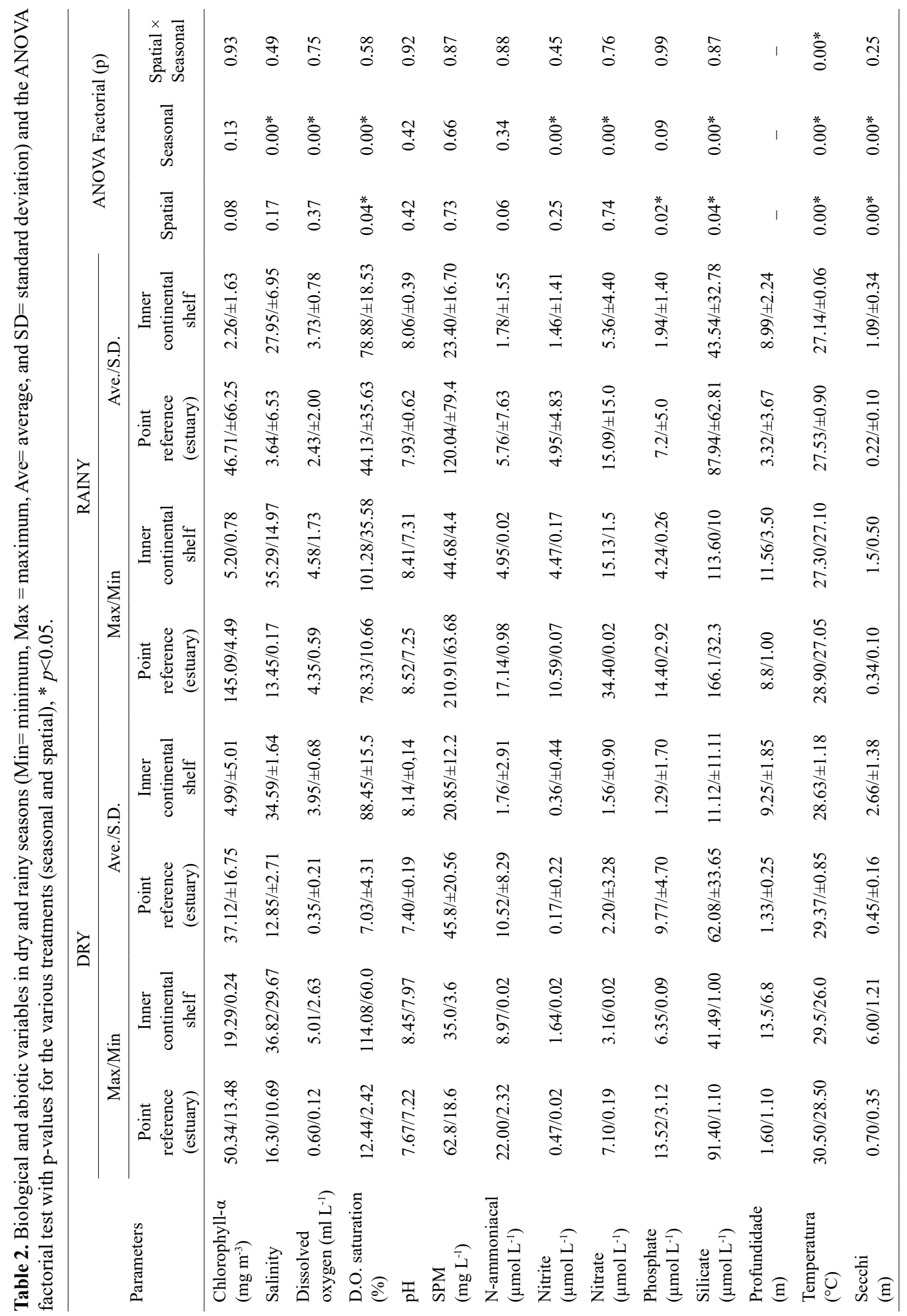




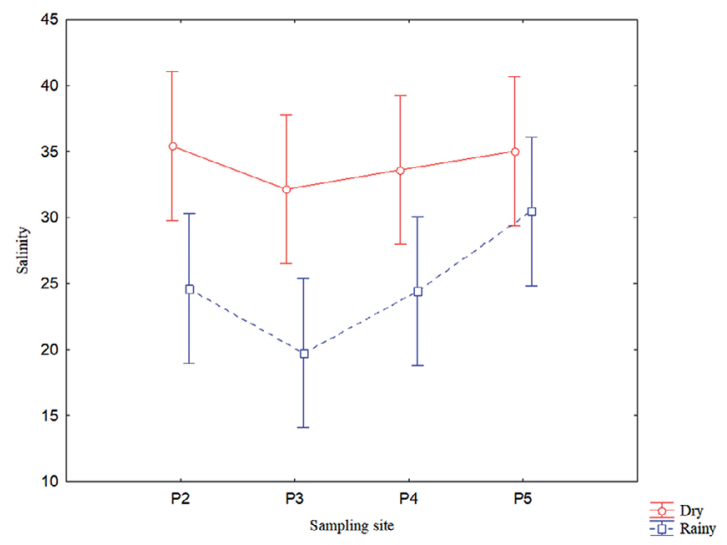

Figure 3. Salinity on the inner continental shelf of Recife Port, PE, Brazil, in dry and rainy seasons.

$\mathrm{m}$ (September/2011). At the inner continental shelf sites, values ranged from $0.5 \mathrm{~m}$ at P3 (July/2010) to $6 \mathrm{~m}$ at P5 (November/2010). Statistically, this parameter presented a seasonal and spatial difference, indicating an increase in the transparency of the water column during the dry season and at the sites furthest from the river mouth (Table 2).

In the estuary (P1), nutrients varied as follows: $\mathrm{N}$-ammoniacal presented a maximum value of $22 \mu \mathrm{mol}$ $\mathrm{L}^{-1}$ (November/2010) and a minimum value of 0.98 $\mu \mathrm{mol} \mathrm{L}{ }^{-1}$ (July/2011); nitrite ranged from $10.59 \mu \mathrm{mol} \mathrm{L}{ }^{-1}$ (July/2010) to undetectable values; nitrate ranged from $34.4 \mu \mathrm{mol} \mathrm{L}^{-1}$ (July/2010) to undetectable values; phosphate ranged from $14.4 \mu \mathrm{mol} \mathrm{L}-1$ (May/2010) to $2.92 \mu \mathrm{mol}$ $\mathrm{L}^{-1}$ (July/2011); silicate showed a variation from 166.1 $\mu \mathrm{mol} \mathrm{L}{ }^{-1}$ (July/2011) to $13.94 \mu \mathrm{mol} \mathrm{L}^{-1}$ (November/2010). For the sites located on the inner continental shelf, the maximum values were all found at P3, which is the point located off the Port of Recife. For N-ammoniacal: 8.97 $\mu \mathrm{mol} \mathrm{L}{ }^{-1}$ (Nov./2010); Nitrite: $4.47 \mu \mathrm{mol} \mathrm{L}^{-1}$ (May./2011); Nitrate: $15.82 \mu \mathrm{mol} \mathrm{L}^{-1}$ (Jul./2011); Phosphate: $6.36 \mu \mathrm{mol}$ $\mathrm{L}^{-1}$ (Nov./2010); Silicate: $113.6 \mu \mathrm{mol} \mathrm{L-1}$ (May/2011).

Statistically, N-ammoniacal showed no significant seasonal or spatial variation, nitrite and nitrate varied seasonally, the highest values being found in the rainy season, phosphate presented spatial differences with the highest values found at P3 and the lowest values at P2 and P5, which are the furthest points from the port entrance, and silicate showed both seasonal and spatial differences, the highest values being found in the rainy season and near the port entrance (Table 2).

The concentration of chlorophyll- $a$ at estuary (P1), the values ranged from $145.09 \mathrm{mg} \mathrm{m}^{-3}$ (May/2010) to $4.49 \mathrm{mg} \mathrm{m}^{-3}$ (May/2011). Phytoplankton biomass showed no significant differences for seasonality and spatiality at the inner continental shelf sites. Nevertheless, the average values in the rainy season were always below those of the dry season. At these sites, chlorophyll- $a$ values ranged from $19.29 \mathrm{mg} \mathrm{m}^{-3}$ at P3 (November/2010) to $0.24 \mathrm{mg} \mathrm{m}^{-3}$ at P5 (March/2011) (Figure 7) (Table 2).

According to PCA, using only the inner continental shelf data, the first two factors accounted for $62,97 \%$ of the correlations between the abiotic data. The first component explained $44,55 \%$, where salinity was directly correlated with $\mathrm{pH}$, od saturation and temperature and inversely correlated with nitrite and silicate. The second component explained $18.42 \%$, directly correlating chlorophyll- $a$ with $\mathrm{N}$-ammoniacal, phosphate and transparency and inversely correlated with suspended particulate matter and nitrate (Figure 8).

\section{DISCUSSION}

The characteristics of the Capibaribe River estuary are mostly determined by the rainfall, which influences the river's flow which, in its turn, affects the continental shelf area through the fluvial plume, thus being capable of modifying the characteristics of this environment. This parameter is reflected in the water quality because by virtue of the amount of terrigenous material displaced, it contributes to the maintenance of an environment conducive to the reproduction and development of species. Due to this discharge, the marine regions are those most affected by the load they receive from the respective drainage basins (Rabalais et al., 1996; Marques et al., 2006; Cloern and Jassby, 2010).

In the present study, the total rainfall observed in 2011 was 58\% higher than that of 2010 and $45.37 \%$ higher than the average of the previous 20 years (1992-2011). In 2011, heavy flooding occurred, mainly in the Metropolitan Region of Recife, due to the principle atmospheric system (Eastern disturbances) which brings rain to the coast of Pernambuco (Anjos et al., 2012). The degree of terrigenous influence in the coastal zone is directly related to rainfall. According to Passavante and Feitosa (2004), there are two annual patterns of phytoplanktonic biomass for the coastal areas of northeastern Brazil, one occurring during the rainy season, when there is algal development due to the increase in the concentration of salt nutrients and light availability, which was also observed by Honorato da Silva et al. (2004) in the Formoso River estuary and Leão et al. (2008) in the Igarassu River estuary, and another in 

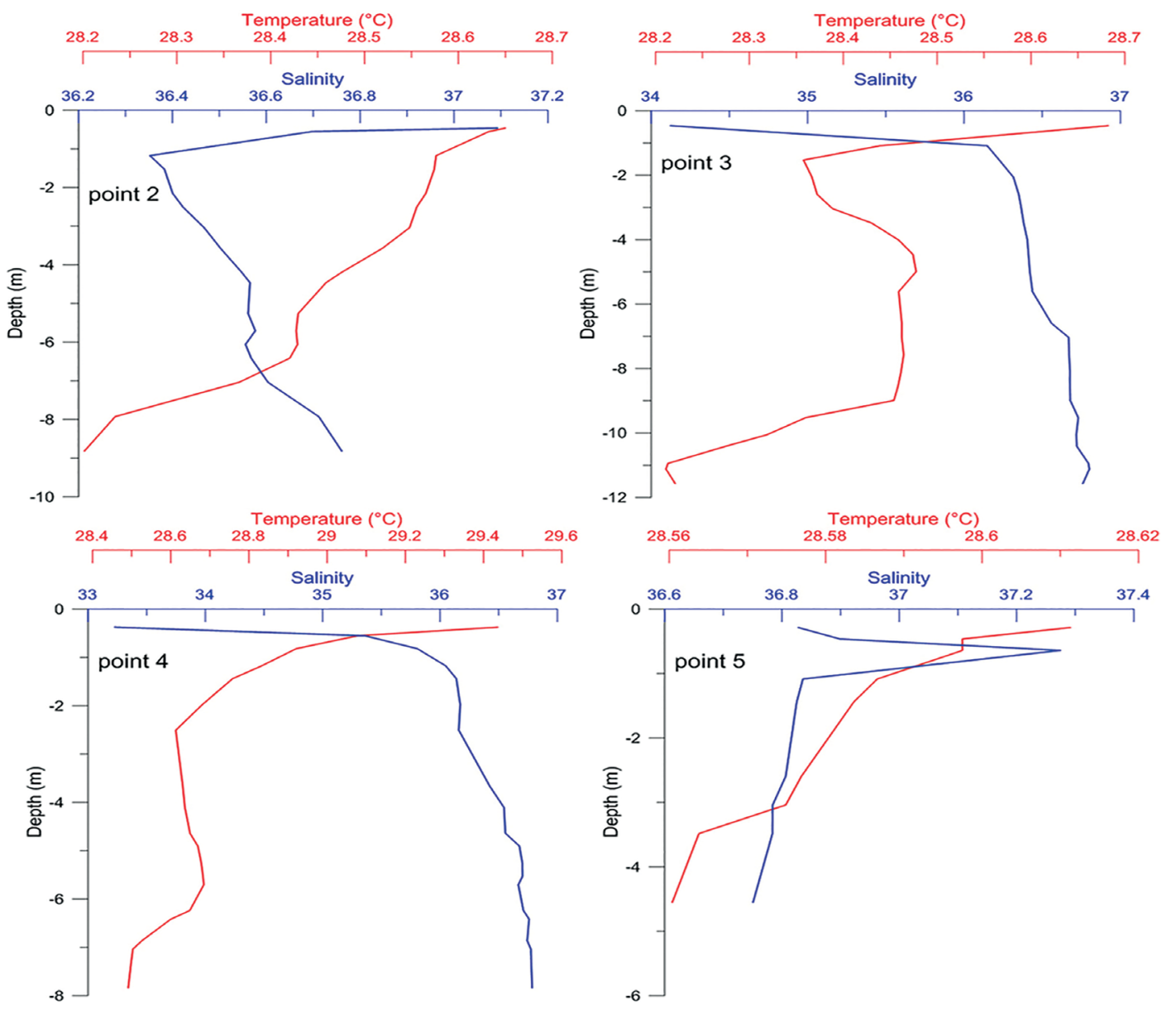

Figure 4. Vertical profiles of temperature and salinity obtained with a CTD during November 2010 at sites P2, P3, P4, and P5.

the dry season, when the increase in the concentration of phytoplankton biomass may be associated with the increase in the euphotic layer, as reported by Azevedo et al. (2008) in the Golfão Maranhense.

The water transparency at the inner continental shelf sites varied seasonally and spatially, higher values occurring uring the dry season and at $\mathrm{P} 5$, the site furthest from the mouth. When the estuary (P1) was added, a spatial variation in suspended particulate matter was observed, with higher values in the rainy season, since the environmental conditions of the estuary were different. This result was confirmed by PCA, which shows this parameter to be inversely related to transparency and directly related to nitrate. Similar patterns were found in the same area by Travassos (1991/1993) and Santiago et al. (2010), and in the Barra das Jangadas estuary by Branco (2007).

Other parameters greatly influenced by rainfall are temperature and salinity. The water temperature in tropical regions is high and its variation is reduced, with temporal stability (Aidar et al., 1993; Agawin et al., 2003).
The study area showed seasonal variation - with higher temperatures occurring in the dry period and lower ones in the rainy season, as recorded by Branco (2007) in the Barra das Jangadas estuary, by Costa et al. (1985) in a profile on the continental shelf in front of the port of Recife, and by Feitosa et al. (1999a) in the Pina Basin.

Regarding the vertical distribution of temperature at the continental sites: both in Nov./2010 and May/2011, the respective variation was of only $0.4^{\circ} \mathrm{C}$ and $0.5^{\circ} \mathrm{C}$, and no thermal stratification was therefore observed during those campaigns. Approximately similar values were recorded by Feitosa et al. (1999a), Anjos et al. (2012), and Noriega et al. (2013) in the port of Recife.

In the case of an environment under strong terrigenous influence, salinity serves as an indicator of the meeting of water bodies of different origins and as a marker of the initial and final limits of an estuary (Feitosa et al., 1999b). This parameter presented a significant seasonal difference, lower values being found in the rainy season. According to the classification of the Venice Symposium, held in 1959, 


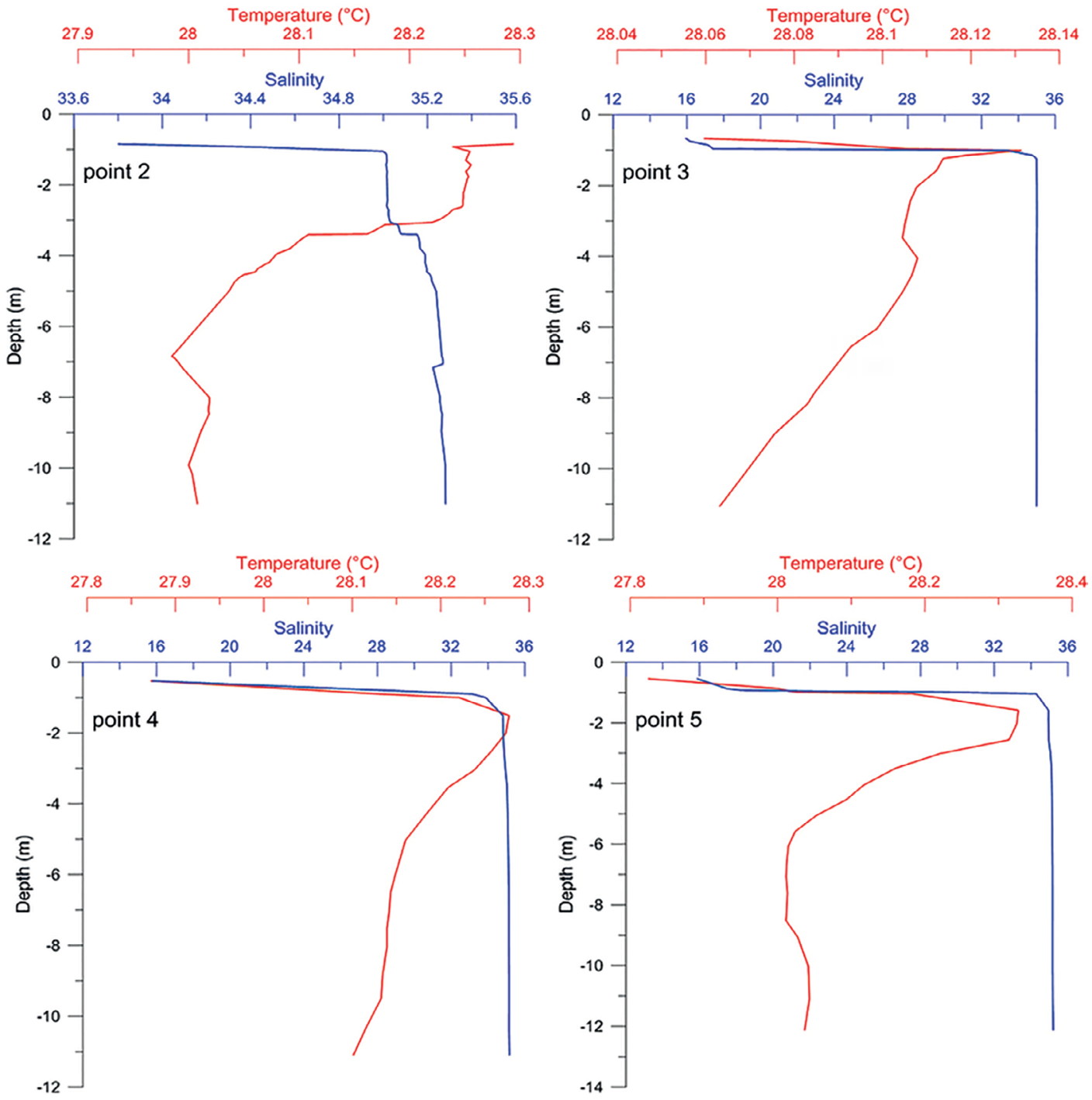

Figure 5. Vertical profiles of temperature and salinity obtained with a CTD during May 2011 at sites P2, P3, P4, and P5.
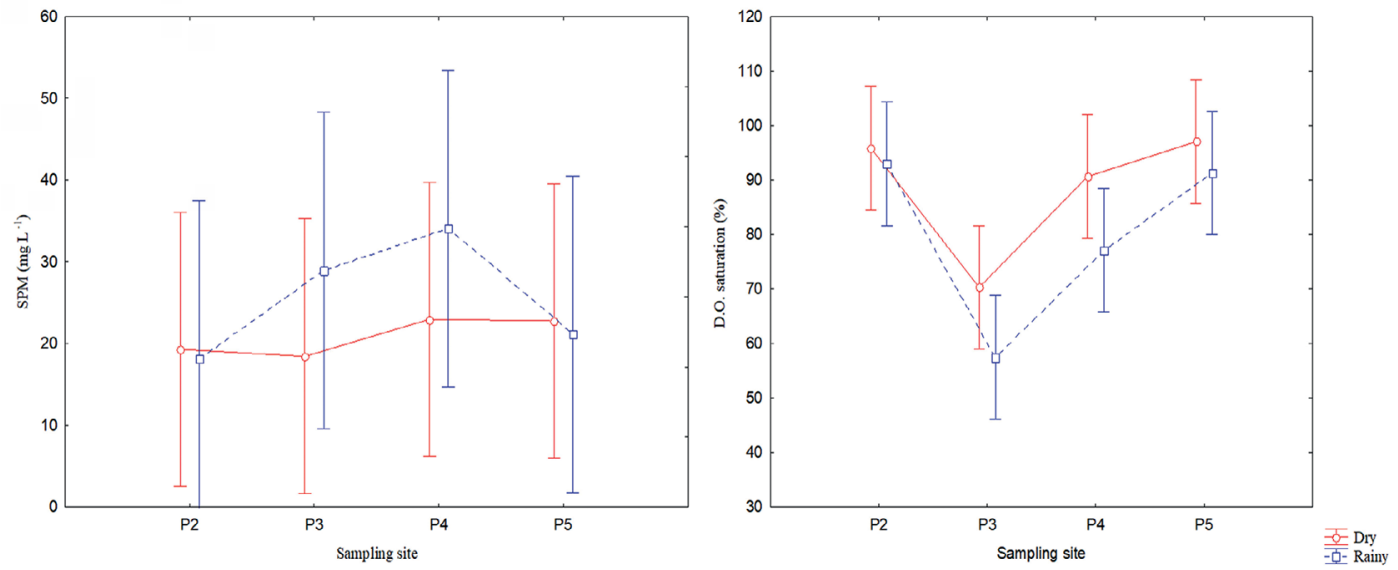

Figure 6. SPM and DO saturation on the inner continental shelf off Recife Port, PE, Brazil, in dry and rainy seasons. 


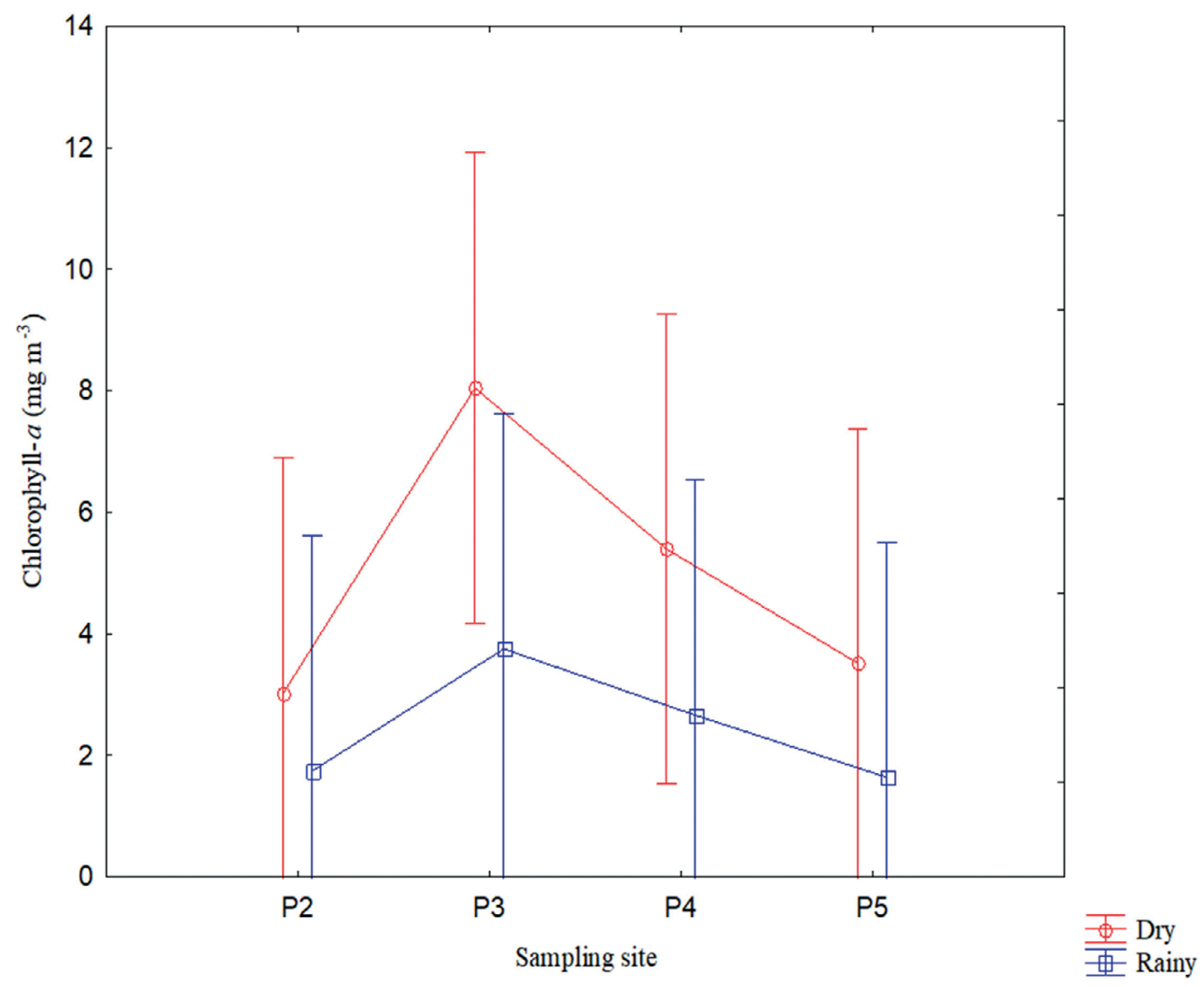

Figure 7. Chlorophyll- $a$ on the inner continental shelf off Recife Port, PE, Brazil, in dry and rainy seasons seasons.
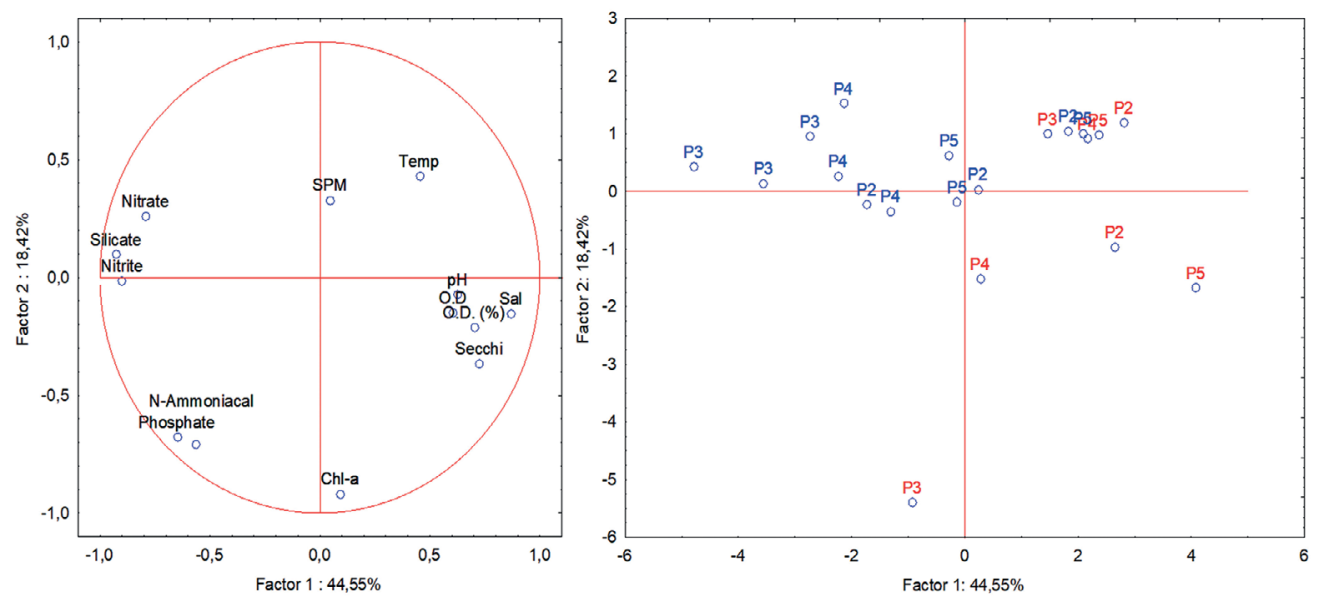

Figure 8. Principal ariable e analysis (PCA) of environmental ariable of the sites on the inner continental shelf off Recife Port, PE, Brazil, analyzed for the two principal ariable es. (A) Ordering of environmental ariable. (SPM=suspended particulate material, $\mathrm{Chl}-\mathrm{a}=$ chlorophylla, Temp=temperature, OD sat.= OD saturation) and diagram of the sampling stations according with dry (red) and rainy(blue) seasons.

whose classes and intervals are reported by Macêdo et al. (2004), throughout the study period the estuary (P1) presented salinity below 17 , being characterized as an environment ranging from meso to oligohaline. Similar results were found by Grego et al. (2009) and Branco (2007); however, Anjos et al. (2012) in the same area found values ranging from limnetic to euhaline, as observed by Feitosa et al. (1999a) in the Pina Basin. 
The inner continental shelf sites (P2, P3, P4 and P5) presented a salinity regime varying between polyhaline and euhaline. Waters classified as polyhaline (salinity $<30$ ) are due to the influence of water from the Capibaribe river plume. The presence of a plume was recorded in the months of May/2011 and July/2011 at all the sites on the inner continental shelf. In May/2011 the predominant wind was southerly and in July/2011 southeasterly, which caused a northerly drift current. It is noteworthy that the presence of the protective dam located in front of the port of Recife causes a certain disturbance as regards the direction of the drainage current, mainly during the period of greatest flow (in the rainy season), and the plume may influence the areas located to the South (P2).

The ADCP conducted in May/2011 revealed the direction of the current, affecting all the sites (Figure 9). P4 also registered fluvial influence in July/2010, as also did $\mathrm{P} 3$, as this latter is located at the exit of the port of Recife. The presence of the plume was intense during almost all the months, except for March/2011 and September/2011, during the dry season, when the rainfall was below the average of the previous 20 years. From the CTD profiles, in the month of November/2010, only saline stratification was observed at P4 and P5, but in May/2011, due to the intense contribution of the rivers, saline stratification was observed at all the sites.

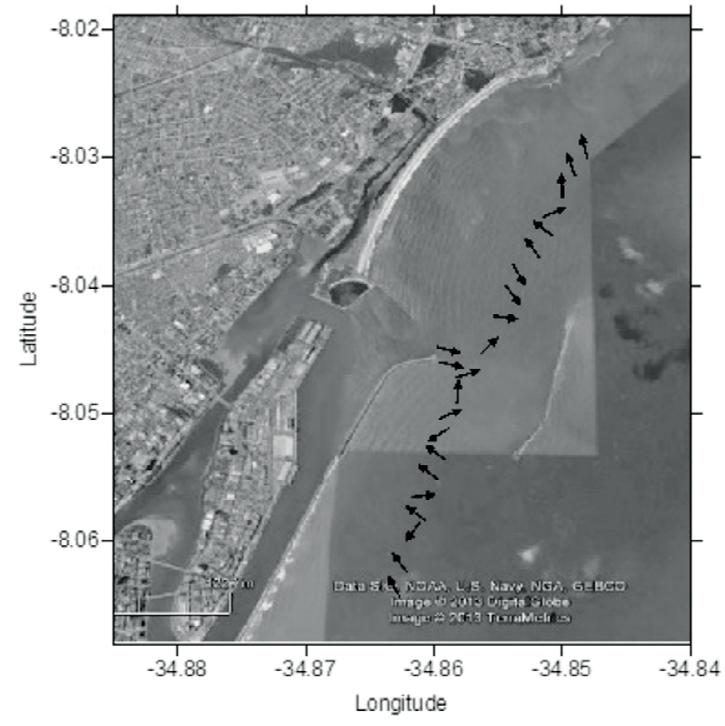

Figure 9. Image of the direction of the currents (ADCP) in the month of May 2011, on the inner continental shelf.
According to Noriega et al. (2005), in the rainy season, factors such as river discharge, low evaporation and high rainfall volume cause a more marked vertical gradient, while in the summer, waters are well mixed and evenly saline. Costa et al. (1985) observed the same on the continental shelf of Pernambuco. The PCA ratifies the presence of the plume at the sites on the platform by inversely relating salinity to nitrite and silicate and directly to $\mathrm{pH}$, temperature and oxygen saturation rate.

Among the gases dissolved in water, oxygen is one of the most important in the dynamics and characterization of aquatic ecosystems. In the estuarine zone (P1), the mean dissolved oxygen values and its saturation rate, rainfall and dry season were: 2.43 and $0.35 \mathrm{ml} \mathrm{L}^{-1}, 44 \%$ and $7 \%$, respectively, according of the classification Macêdo and Costa (1978), this site was characterized as being in a semi-polluted zone in the winter and in a polluted zone in the summer. Feitosa et al. (1999a), Santiago et al. (2010), Santos et al. (2009) and Travassos (1991/1993), found similar values in the same area. The sites on the inner continental shelf were classified as belonging to a saturated zone. On the continental shelf near the Jaboatão River, Costa et al. (1985) found water saturated with oxygen, attributed to the intense mixing process caused by waves and tidal currents, as well as to the process of photosynthesis. Mafalda et al. (2004) always found saturated values on the northern coast of Bahia, but no seasonal or spatial variation was observed, as in the present study.

At all the sites, the $\mathrm{pH}$ was always alkaline, which shows the great marine influence in the study area; however, P1 presented the lowest values, reaching 7.22, and the coastal sites, the highest values. This parameter is directly related to the amount of carbon dioxide and dissolved oxygen due to its relation to the amount of decomposing organic matter (Macêdo, 1974; Santos, 2010). PCA relates $\mathrm{pH}$ directly to salinity, oxygen rate and temperature and inversely to silicate and nitrite. Previous research carried out in the study area has found similar results (Santos et al., 2009; Feitosa et al., 1999a; Travassos, 1991/1993).

In the estuary $(\mathrm{P} 1)$, as expected, the nutrient values were higher than those recorded on the inner continental shelf., possibly due to the release of domestic effluents.

Comparing the concentrations recorded in this study with previous research undertaken in the region, Travassos (1991/1993), Feitosa et al. (1999a) and Nascimento et al. 
(1999b), registered similar values for this parameter and reported that an important fact to be considered was that since no thermal stratification occurred, the mixing in the water column became easier as also did the detachment of nutrient salts from the bottom, thus favoring the phytoplankton community.

At the sites closest to the coast, nutrient concentrations were lower than those found in the estuary. The influence of a river's flow on the distribution of nutrients and organic matter in estuarine systems and coastal areas generally results in a decrease in the concentrations of these compounds and increased salinity (Schettini et al., 2000; Nascimento et al., 2003; Gago et al., 2005).

This fact was established by PCA, which directly related nitrite and silicate to each other and inversely related them to salinity, oxygen saturation rate, $\mathrm{pH}$ and temperature, chlorophyll- $a$ to N-ammoniacal, and phosphate inversely to nitrate. The inverse relation mainly of nitrite to the oxygen saturation rate is elucidated by the process of the decomposition of organic matter that explains these variations which result from an increase of aerobically decomposed organic compounds and which decrease the concentration of oxygen in this environment. The more pronounced increase of nitrite also evidences the consumption of oxygen by the nitrification process (Kuroshima and Bellotto, 2009).

When comparing the nutrient content found in this study with that found by Braga et al. (2000) in the sea adjacent to the Baixada Santista, the values at the continental shelf sites were much higher, thus confirming the continental influence at those sites. Mafalda et al. (2003) in the Baía de Todos os Santos region, found values compatible with oligotrophy.

Chlorophyll- $a$ in association with some physical and chemical parameters, acts as a tool to detect possible changes in water quality and evaluate temporal trends that result in changes in the habitat, trophic structure or behavior of aquatic organisms, an evaluation which is mandatory in environmental monitoring work (Ancona et al., 2006; Smith, 2007).

The concentrations of chlorophyll- $a$ observed in the estuarine area $(\mathrm{P} 1)$ were much higher than those observed on the inner continental shelf due to the intense anthropic action undertaken in the former environment, possibly resulting in a flowering, commonly found in this estuary (Travassos, 1991/1993; Feitosa et al., 1999; FloresMontes et al., 2011; Paulo et al., 2011). According to PCA, chlorophyll- $a$ showed an inverse relationship with suspended particulate matter and nitrate and a direct effect on $\mathrm{N}$-ammoniacal, phosphate and transparency.

Although chlorophyll- $a$ presented no significant variation for seasonality, higher concentrations were observed in the dry season. Anjos et al. (2012), Feitosa and Passavante (1990) and Resurreição et al. (1996) also found higher phytoplankton biomass values in the dry period, due to the increase of the euphotic layer.

At the inner continental shelf sites, higher concentrations were observed in November/2010, possibly due to the increase in $\mathrm{N}$-ammoniacal concentrations. This fact was highlighted by PCA, which directly relates chlorophyll- $a$ to N-ammoniacal.

Similar values found on the inner continental shelf sites were recorded by Mafalda et al. $(2003 ; 2004)$ in the Baía de Todos os Santos region and the northern coast of Bahia, found lower concentrations with averages between $0.13-2.8 \mathrm{mg} \mathrm{m}^{-3}$, being characteristic of oligotrophic environment. Souza et al. (2008), analyzing the temporal variation of the phytoplankton in the coastal zone of Pará, observed a maximum value of $8.70 \mathrm{mg} \mathrm{m}^{-3}$.

According to Noriega et al. (2013), previous research in the port of Recife and the adjacent estuary shows that rainfall - and consequently the contribution of the Beberibe and Capibaribe Rivers and Pina waters - is capable of affecting the port area and producing temporal and spatial changes in the dynamics of coastal waters and phytoplankton biomass, as was observed in this study.

\section{CONCLUSION}

Therefore, in the light of Vollenweider and Kerekes's (1982) classification of coastal water quality, the inner continental shelf adjacent to the port of Recife varies between mesotrophic at the most central sites (P3 and P4) and oligotrophic at the more distant ones (P2 and P5). However, it is worth mentioning that there are certain moments, depending on the flow of the rivers concerned, when it can reach eutrophic levels as a consequence of the excess of domestic effluents discharged into the environment.

\section{ACKNOWLEDGEMENT}

The authors thank the CARECOS Project, with financial support of the Foundation for Science and Technology Support of Pernambuco (FACEPE/ FAPESP APQ-0074-1.08/11) and the Research Support Foundation of the State of São Paulo (FAPESP/ FACEPE/ANR 2011/50582-0). 


\section{REFERENCES}

ABESSA, D. M. S., RACHID, B. R. F., MOSER, G. A. O. \& OLIVEIRA, A. J. F. C. 2012. Efeitos ambientais da disposição oceânica de esgotos por meio de emissário submarinos: uma revisão. Mundo da Saúde, 36, 643-661.

ANCONA, C. M., SALDANHA-CORRÊA, F. M. P, STEPHAN, M. \& GIANESELLA, S. M. F. 2006. Variação espaço-temporal da biomassa no estuário e baía de Santos. In: BRAGA, E. S. (ed.) Oceanografia e mudanças globais. III simpósio brasileiro de oceanografia. São Paulo: Instituto Oceanográfico de São Paulo.

AGAWIN, N. S. R., DUARTE, C. M., AGUSTÍ, S. \& MCMANIUS, L. 2003. Abundance, biomass and growth rates of Synechococcus sp. in a tropical coastal ecosystem (Philippines, South China Sea). Estuarine, Coastal Shelf Science, 56, 493502.

AIDAR, E., GAETA, S. A., GIANESELlA-GALVÃO, S. M. F., KUTNER, M. B. B. \& TEIXEIRA, C. 1993. Ecossistema costeiro subtropical: nutrientes dissolvidos, fitoplâncton e clorofila- $a$ e suas relações com as condições oceanográficas na região de Ubatuba (SP). Publicação Especial do Instituto Oceanográfico, 10, 9-13.

ANJOS, D. L., PASSAVANTE, J. Z. O., SILVA-CUNHA, M. G. G. \& HONORATO DA SILVA, M. 2012. Biomassa fitoplanctônica correlacionada aos fatores hidrológicos no estuário do rio Capibaribe (Recife, Pernambuco, Brasil). Tropical Oceanography, 40, 167-184.

ARAÚJO, M., MEDEIROS, C. \& RIBEIRO, C. 1999. Energy balance and time-scales of mixing and stratification in the Jaboatão estuary, NE-Brazi. Revista Brasileira de Oceanografia, 47, 145-154.

AZEVEDO, A. C. G., FEITOSA, F. A. N. \& KOENING, M. L. 2008. Distribuição espacial e temporal da biomassa fitoplanctônica e variáveis ambientais no Golfão Maranhense, Brasil. Acta Botanica Brasilica, 22, 870-877.

BAUMGARTEN, M. G. Z., ROCHA, J. M. B. \& NIENCHESKI, L. F. H. 1996. Manual de análises em oceanografia química, Rio Grande, FURG.

BRAGA, E., BONETTI, C. V. D. H., BURONE, L. \& BONETTI-FILHO, J. 2000. Eutrophication nd bacterial pollution caused by industrial and domestic wastes at the Baixada Santista estuarine system - Brazil. Marine Pollution Bulletin, 40, 165173.

BRANCO, E. S. 2007. Influência das variáveis ambientais na comunidade fitoplanctônica estuarina. Recife, Universitária da UFPE.

CLOERN, J. E. \& JASSBY, A. D. 2010. Patterns and Scales of Phytoplankton Variability in Estuarine-Coastal Ecosystems. Estuaries and Coasts, 33, 230-241.

COSTA, K. M. P., QUEIROZ, C. M. \& MACÊDO, S. J. 1985. Hidrologia e plankton da Plataforma Continental de Pernambuco 1. Variação das características físico-químicas da água. In: Encontro Brasileiro de Gerenciamento Costeiro III, Fortaleza, 337-371.

FEITOSA, F. A. N., NASCIMENTO, F. C. R. \& COSTA, K. M. P. 1999a. Distribuição especial e temporal da biomassa fitoplanctônica relacionada com parâmetros hidrológicos na Bacia do Pina (Recife-PE). Trabalhos Oceanográficos Universidade Federal de Pernambuco, 27(2), 1-13.
FEITOSA, F. A. N., SILVA-CUNHA. M. G. G., PASSAVANTE, J. Z. O., NEUMANN-LEITÃO, S. \& CORREIA LINS, I. 1999b. Estrutura do microfitoplâncton no sistema estuarino do rio Goiana, Pernambuco, Brasil. Trabalhos Oceanográficos Universidade Federal de Pernambuco, 27, 15-25.

FLORES MONTES, M.J.; PAULO, J.G.; NASCIMENTO FILHO, G.A.; GASPAR, F.L.; FEITOSA, F.A.; SANTOS JÚNIOR, A.C.; BATISTA, T.N.F.; TRAVASSOS, R.K.; PITANGA, M.E. 2011. The trophic status of an urban estuarine complex in Northeast Brazil. Journal of Coastal Research, 64(SI): 408-411" :http://www.cerf-jcr.org/images/stories/2011_ICS_ Proceedings/SP64_408-411_M.deJ.Flores_Montes.pdf

GAGO, J., ÁlVAREZ-SAlGADO, X. A., M., NIETO-CID, M., BREA, S. \& PIEDRACOBA, S. 2005. Continental inputs of C, N, P and Si species to the Ria de Vigo (NW Spain). Estuarine, Coastal and Shelf Science, 65, 74-82. DOI: 10.1016/j. ecss.2005.05.008

GRASSHOFF, K., EHRHARDT, M. \& KREMLING, K. 1983. Methods of seawaters analysis, $2^{\mathrm{a}}$ ed. Weinheim, Wiley-Verlag Chemie.

GREGO, C. K. S., FEITOSA, A. N., SILVA, M. H., CUNHA, M. G. G. S. \& NASCIMENTO FILHO, G. A. 2009. Fitoplâncton do ecossistema estuarino do rio Ariquindá (Tamandaré, Pernambuco, Brasil): variáveis ambientais, biomassa e produtividade primária. Atlântica, 31, 183-198.

HONORATO SILVA, M., PASSAVANTE, J. Z. O., SILVA-CUNHA, M. G. G., NASCIMENTO VIEIRA, D. A., GREGO, C. K. S. \& MUNIZ, K. 2004. Distribuição especial e sazonal da biomassa fitoplanctônica e dos parâmetros hidrológicos no estuário do rio Formoso (rio Formoso, Pernambuco, Brasil). Tropical Oceanography, 32, 89-106.

KUROSHIMA, K. N \& BELLOTO, V. R. 2009. Dinâmica dos nutrientes inorgânicos e orgânicos na Foz do Rio Itajaí-Açú. In: BRANCO, J. O., LUNARDON-BRANCO, M. J. \& BELLOTTO, V. R. (org.) Estuário do Rio Itajaí-Açú, Santa Catarina: caracterização ambiental e alterações antrópicas. Itajaí: Editora Univali.

LEÃO, B. M., PASSAVANTE, J. Z. O., SILVA-CUNHA, M. G. G. \& SANTIAGO, M. F. 2008. Ecologia do microfitoplâncton do estuário do rio Igarassu, PE, Brasil. Acta Botanica Brasilica, 22, 711-722.

MACÊDO, S. J. Fisioecologia de alguns estuários do Canal de Santa Cruz (Itamaracá - Pernambuco).Dissertação de Mestrado, Universidade de São Paulo, 121 p., São Paulo, 1974.

MACÊDO, S. J., MUNIZ, K. \& FLORES MONTES, M. J. 2004. Hidrologia da região costeira e plataforma continental do Estado de Pernambuco. In: ESKINAZI-LEÇA, E. NEUMANN-LEITAO, S. \& COSTA, M. F. (eds.) Oceanografia: um cenário tropical. Recife: Bagaço.

MACÊDO, S. J. \& COSTA, K. M. P. 1978. Estudo ecológico da região de Itamaracá Pernambuco - Brasil, condições hidrológicas do estuário do rio Botafogo. Ciência e Cultura, 30, 1-368.

MAFALDA, JR., P. O., SINQUE, C., BRITO, R. R. C. \& SANTOS, J. J. 2004. Biomassa planctônica, hidrografia e pluviosidade na costa norte da Bahia, Brasil. Tropical Oceanography, 32, 143-158.

MAFALDA, JR, P. O., SOUZA, P. M. M. \& SILVA, E. M. 2003. Estrutura hidroquímica e biomassa planctônica no Norte da Baía de Todos os Santos, Bahia, Brasil. Tropical Oceanography, 31, 31-51. 
MAFALDA, JR, P. O., MOURA, G. F., MELO, G. N., SAMPIO, J. A. A., FEITOSA, F. A. N., PASSAVANTE, J. Z. O., MOREIRA, M. O. \& SOUZA, C. S. 2009. Oceanografia Biológica: Biomassa fitoplanctônica na ZEE da região Nordeste do Brasil. In: HAZIN, F. H. V. (org.) Coleção Programa REVIZEE- SCORE- NE. Fortaleza: Martins \& Cordeiro.

MARQUES, C. W. MONTEIRO, I. O., MÖLLER, O. \& FERNANDES, E. H. A. 2006. Dinâmica da pluma costeira da Lagoa dos Patos, Brasil. In: Seminário e workshop em engenharia oceânica II, Rio Grande. Available from: http://repositorio.furg.br/handle/1/946 [Accessed 2018 Mar 9].

MEDEIROS, C., MACEDO, S. J. FEITOSA, F. A. N. \& KOENING, M. L. 1999. Hidrography and phytoplankton biomass and abundance of North-East Brazilian waters. Archive of Fishery and Marine Research, 47, 133-151.

MOURA, R.T., E PASSAVANTE, J.Z.O., 1994/1995. Biomassa fitoplanctônica da baía de Tamandaré, Rio Formoso-Pernambuco, Brasil. Trabalho Oceanográfico. Universidade Federal de Pernambuco, 23, p.1-15.

NASCIMENTO, F. C. R., MUNIZ, K., FEITOSA, F. A. N., ARAÚJO, J. P., SILVA, R. M. S., SILVA, G. S. \& FLORES MONTES, M. J. 2003. Disponibilidade nutricional da Bacia do Pina e rio Tejipió (Recife-PE-Brasil) em relação aos nutrientes e biomassa primária (setembro/2000). Tropical Oceanography, 31, 149-169.

NORIEGA, C. E. D., SANTIAGO, M. F., FAÇANHA, P., SILVA-CUNHA, M. G. G., SILVA, R. A., FLORES MONTES, M. J, ARAÚJO FILHO, M., COSTA, K. M. P., ESKINAZI-LEÇA, E. \& NEUMANN-LEITÃO, S. 2013. The instantaneous transport of inorganic and organic material in a highly polluted tropical estuary. Marine and Freshwater Research, 64, 562-572.

NORIEGA, C. E. D., COSTA, K. M. P., FEITOSA, F. A. N., MONTES, M. J. F., GREGO, C. K. S., SOARES, G. S. S. \& SILVA, H. P. 2005. Distribuição espacial da biomassa fitoplanctônica e sua relação com os sais nutrientes, no sistema estuarino de Barra das Jangadas (Pernambuco - Brasil). Arquivos de Ciência do Mar, 38, 5-18.

PASSAVANTE, J. Z. O. \& FEITOSA, F. A. N. 2004. Dinâmica da Produtividade Fitoplanctônica na Zona Costeira Marinha. In: ESKINAZI-LEÇA, E., NEUMANN-LEITÃO, S. \& COSTA, M. F. (eds.) Oceanografia: um cenário tropical. Recife: Bagaço.

PASSAVANTE, J.Z.O.; FEITOSA, F.A.N. 1995. Produção primária do fitoplâncton da plataforma continental de Pernambuco (Brasil): área de Piedade. Boletim Técnico e Cientifico de CEPENE, v.3, n.1, p.7-22.

PAULO, J. G., FLORES MONTES, M. J., SANTOS JÚNIOR, A. C., BATISTA, T. N. F., TRAVASSOS, R. K., NASCIMENTO FILHO, G. A., FEITOSA, F. A., GASPAR, F. L. \& PITANGA, M. E. 2011. Allochthonous and autochthonous organic matter in na urban tropical estuarine área of northeastern Brazil. Journal of Coastal Research, 64, 1798-1801.

PORTO DO RECIFE. 2013. Available from: http://www.portodorecife.pe.gov.br/ [Accessed 2015 Oct 10].

RABALAIS, N. N., TUMER, R. E., JUSTIC, D., DORTCH, Q., WISEMAN, W. J. \& SEM GUPTA, B. K. 1996. Nutrient changes in the Mississippi river and system responses on the adjacente continental shelf. Estuaries, 19, 386-407.

RESURREIÇÃO, M. G.; PASSAVANTE, J. Z. O. \& MACÊDO, S. J. 1996. Estudo da Platafoma Continental na área do Recife (Brasil): variação sazonal da biomassa fitoplanctônica ( $08^{\circ} 03^{\prime} 38^{\prime \prime}$ lat. S; 34²'28" à 3452'00" long. W.). Trabalhos Oceanográficos Universidade Federal de Pernambuco, 24, 39-59.
SANTIAGO, M. F., SILVA-CUNHA, M. G. G., NEUMANN-LEITÃO, S., COSTA, K. M. P., PALMEIRA, G. C. B., PORTO NETO, F. F. \& NUNES. F. S. 2010. Phytoplankton dynamics in a highly eutrophic estuary in tropical Brazil. Brazilian Journal of Oceanography, 58, 189-205.

SANTOS, M. L. S. \& MUNIZ, K. 2010. Variação nictemeral de parâmetros abióticos e clorofila $a$ em uma estação oceanográfica na plataforma continental do Amazonas. Atlântica, 32, 237-246.

SANTOS, T. G., BEZERRA-JÚNIOR, J. L., COSTA; K. M. P. \& FEITOSA, F. A. N. 2009. Dinâmica da biomassa fitoplanctônica e variáveis ambientais em um estuário tropical (Bacia do Pina, Recife, PE). Revista Brasileira de Engenharia de Pesca, 4, 95-109.

SOUZA, E.B., costa, V.B., PEREIRA, L.C.C. e COSTA, R.M., 2008. Variação temporal do fitoplâncton e dos parâmetros hidrológicos da zona de arrebentação da Ilha Canela (Bragança, Pará, Brasil). Acta. Botanica Brasilica, 23(4), 626-636

SCHETTINI, C. A. F., PEREIRA FILHO, J. \& SPPILERE, L. C. 2000. Caracterização Oceanográfica e Biogeoquímica dos Estuários dos Rio Tavares e Defuntos, Reserva Extrativista de Pirajubaé, Florianópolis, SC, Brasil, Notas Técnicas da Facimar, 4, 11-28.

SRHE (Secretaria de Recursos Hídricos do Estado de Pernambuco). 2010. Plano hidroambiental da bacia hidrográfica do rio Capibaribe. Available from: http://www.sirh.srh.pe.gov. br/hidroambiental/files/capibaribe/TOMO $\% 20 I I \% 20-\% 20$ Relatorio\%20Planos\%20de\%20Investimentos-26\%2007\%20 11.pdf [Accessed 2018 Mar 9].

SMITH, V. H. 2007. Using primary productivity as an index of coastal eutrophication: the units of measurement matter. Journal of Plankton Research, 29, 1-6.

STACEY, M. T., COWEN, E. C., POWELL, T. M., DOBBINS, E. MONISMITH, S. G. \& KOSEFF, J. 1999. Plume dispersion in a stratified, near-coastal flow: measurements and modeling. Continental Shelf Research, 20, 637-663.

STRICKLAND, J. D. H. \& PARSONS, T. R. 1972. A pratical handbook of seawaters analysis. A Pratical Handbook of Seawater Analysis. Bulletin 167, $2^{\text {nd }}$ ed. Ottawa, Fisheries Research Board of Canada.

TRAVASSOS, P. E. P. F., MACÊDO S. J. \& KOENING, M. 1991/1993. Aspectos hidrológicos do estuário do rio Capibaribe (Recife, Pernambuco, Brasil). Trabalhos Oceanográficos Universidade Federal de Pernambuco, 22, 9-38.

UNESCO. 1973. International Oceanographic Tables, Paris, National Institute of Oceanography of Great Britain, Wormley, and United Nations Educational, Scientific and Cultural Organization (UNESCO).

UNESCO. 1966. Determination of photosynthetic pigments in sea waters. Report of SCOR/UNESCO working group 17 with meat from 4 to 6 June 1964. (Monographys on Oceanology Methodology), Paris, UNESCO.

VALIELA, I. 1995. Marine ecological processes. $2^{\text {nd }}$ ed, New York, Springer Verlag.

VOLLENWEIDER, R. A. \& KEREKES, J. 1982. Eutrophication of waters: monitoring, assessment and control. Report of the OECD cooperative program on Eutrophication, Paris, Organization for the Economic Development and Co-operation. 